\title{
Temporality and Space in Cien años de soledad
}

\author{
Jay Corwin $^{1}$
}

The use of distinct time frames is often commented upon in the criticism of García Márquez's Cien años de soledad. Progress and retrograde time exist at once in the text in the same manner as Alejo Carpentier's Los pasos perdidos and Rulfo's Pedro Páramo, both of which regress temporally into the American past. Critical difficulties in the reconciliation of the spatial with the temporal in Cien años de soledad, including identification of the novel with Old World myths, may result from a tendency to ignore American aesthetics in the assessment of literary arts in the Americas. The pressure to view an Anglo-American imprint on Latin American literary culture, vague terms such as "The Boom" and "Magical Realism," and Eurocentric poststructuralism may have diverted attention from authentic technical innovation and trends in Latin American literary arts. Cien años de soledad, like other mid $20^{\text {th }}$ Century Latin American novels, may only be understood within its cultural context. This necessitates critical reconciliation of locus with temporal structures, i.e., the recognition that retrograde time leads to pre-contact Americas rather than to Europe. [Article copies available for a fee from The Transformative Studies Institute. E-mail address: journal@transformativestudies.org Website: http://www.transformativestudies.org (C2011 by The Transformative Studies Institute. All rights reserved.]

KEYWORDS: Cien años de soledad, Gabriel García Márquez, Temporality, Space, Alejo Carpentier, Jorge Luis Borges, Octavio Paz, González Echevarría, Gerald Martin, Los pasos perdidos, Pedro Páramo, William Faulkner, Tzvetan Todorov, Conquest of the Americas.

\footnotetext{
${ }^{1}$ Jay Corwin, Ph.D., is Senior Lecturer of Spanish at the University of Cape Town in South Africa. He received his Ph.D. in Spanish from Florida State University in 1995. His first book was La transposición de fuentes indígenas en Cien años de soledad [The Transposition of Indigenous Sources in One Hundred Years of Solitude], (Romance Monographs number 52, 1997). He recently gave a keynote presentation at an international conference in Lima, Peru, to mark the fortieth anniversary of the publication of One Hundred Years of Solitude. His recent publications include articles about the works of Gabriel García Márquez, Juan Rulfo and other contemporary Latin American novelists. He is currently working on a book about myth in the novels of Gabriel García Márquez, and editing a volume of essays on One Hundred Years of Solitude for Rodopi Press's Dialogue Series. Address correspondence to: Jay Corwin, University of Cape Town; e-mail: jay.corwin@uct.ac.za.
}

1937-0229 (2011 Transformative Studies Institute 